\title{
Online Yorumların Tüketici Satın Alma Kararına Etkisi: Kullanıcı Özellikleri Açısından Bir Değerlendirme* (The Effect of Online Reviews on Consumer Buying Decision: An Evaluation of User Characteristics)
}

\section{Peruze Cansu AKDENiz iD a Tuğba ÖZBÖLÜK iD b}

a Bozok Üniversitesi, Sosyal Bilimler Enstitüsü, Yozgat, Türkiye. cansundergmail.com

b Bozok Üniversitesi, İktisadi ve İdari Bilimler Fakültesi, Yozgat, Türkiye. tugba.ozboluk@bozok.edu.tr

\begin{tabular}{|c|c|}
\hline MAKALE BİLGİsİ & ÖZET \\
\hline $\begin{array}{l}\text { Anahtar Kelimeler: } \\
\text { Online Tüketici Yorumlar1 }\end{array}$ & $\begin{array}{l}\text { Amaç - Bu araştırmanın amacı ürüne yönelik online tüketici yorumlarının satın alma üzerindeki } \\
\text { etkisinin kullanıcının özelliklerine göre farklılaşıp farklılaşmadığını belirlemektir. }\end{array}$ \\
\hline $\begin{array}{l}\text { Online Ürün Yorumları } \\
\text { Tüketici Satın Alma Karar } \\
\text { Süreci }\end{array}$ & $\begin{array}{l}\text { Yöntem - Çalışmanın evrenini Türkiye'de online tüketici yorumlarını okuyan internet kullanıcıları } \\
\text { oluşturmaktadır. Çalışmanın örneklemini, Kayseri ilinde ikamet eden ve kolayda örneklem } \\
\text { yöntemine göre belirlenen } 522 \text { katılımcı oluşturmaktadır. Araştırmanın verilerini toplamak için } \\
\text { yüz yüze anket çalışması yapılmıştır. Anket sonucunda elde edilen verilere Tek Yönlü MANOVA } \\
\text { analizi uygulanmıştır. }\end{array}$ \\
\hline $\begin{array}{l}2019 \\
\text { Revizyon Tarihi } 11 \text { Aralık } 2019 \\
\text { Kabul Tarihi } 15 \text { Aralık } 2019\end{array}$ & $\begin{array}{l}\text { Bulgular - Araştırma sonucunda online yorumların tüketicilerin satın alma kararı üzerindeki } \\
\text { etkisinin tüketicilerin cinsiyet, yaş grupları ve günlük internet kullanım süresi değişkenlerine göre } \\
\text { anlamlı bir farklılık göstermediği sonucuna ulaşılmıştır. Anlamlı farklılık gösteren tek değişkenin } \\
\text { "tüketicilerin online alışveriş sıklıkları" olduğu bulunmuştur. }\end{array}$ \\
\hline $\begin{array}{l}\text { Makale Kategorisi: } \\
\text { Araştırma Makalesi }\end{array}$ & $\begin{array}{l}\text { Tartışma - Online yorumların tüketici satın alma kararını etkilediği ve tüketicilerin online alışveriş̧ } \\
\text { sıklıkları arttıkça web sitesinin özellikleri ve yorumun özelliklerinin satın alma kararları üzerinde } \\
\text { daha etkili olduğu ortaya çıkmıştır. }\end{array}$ \\
\hline
\end{tabular}

\begin{tabular}{|c|c|}
\hline ARTICLE INFO & ABSTRACT \\
\hline $\begin{array}{l}\text { Keywords: } \\
\text { Online Consumer Reviews }\end{array}$ & $\begin{array}{l}\text { Purpose - The main purpose of this study is to examine whether the impact of online consumer } \\
\text { reviews on consumers' purchasing decision differs according to their characteristics. }\end{array}$ \\
\hline $\begin{array}{l}\text { Online Product Reviews } \\
\text { Consumer Decision Making } \\
\text { Process }\end{array}$ & $\begin{array}{l}\text { Design/methodology/approach - The population of the study consists of the Internet users who } \\
\text { read online consumer reviews in Turkey. The sample of the study is composed of } 522 \text { participants } \\
\text { in Kayseri determined according to the convenience sampling method. In order to collect the data, } \\
\text { a face-to-face survey has been conducted. One-way MANOVA is applied to the data collected } \\
\text { from the survey. }\end{array}$ \\
\hline $\begin{array}{l}\text { Revised } 11 \text { December } 2019 \\
\text { Accepted } 15 \text { December } 2019\end{array}$ & $\begin{array}{l}\text { Findings - As a result of the study, findings show that the effect of online reviews on consumer } \\
\text { purchase decision does not show a significant difference according to their gender, age groups and } \\
\text { daily internet usage. The only significant difference is found for the variable "online shopping } \\
\text { frequency of consumers". }\end{array}$ \\
\hline Research Article & $\begin{array}{l}\text { Discussion - Online reviews have an impact on consumers' purchasing decision, and increased } \\
\text { level of online shopping frequency has more influence on their decision in terms of web site and } \\
\text { online review characteristics. }\end{array}$ \\
\hline
\end{tabular}

\footnotetext{
* Bu makale, birinci yazarın ikinci yazar danışmanlığında Bozok Üniversitesi Sosyal Bilimler Enstitüsünde 2019 yılında hazırladığı Tüketicilerin satın alma kararında online ürün yorumlarından etkilenme düzeyinin belirlenmesine yönelik bir araştırma başlıklı tezden üretilmiştir.
}

\section{Önerilen Atıf/Suggested Citation}

Akdeniz, P. C., Özbölük, T. (2019) Online Yorumların Tüketici Satın Alma Kararına Etkisi: Kullanıcı Özellikleri Açısından Bir Değerlendirme, işletme Araştırmaları Dergisi, 11 (4), 3104-3119. 


\section{Giriş}

İnternetin ortaya çıkışı ve yaygınlaşması elektronik ağıdan ağıza iletişimin de giderek yaygınlaşmasına neden olmuştur. Elektronik ağızdan ağıza iletişim, tüketicinin bilgi, düşünce ve deneyimlerinin internet ortamındaki çeşitli kanallar aracılığıyla iletilmesi ve başka kullanıcılarla da bu sürecin paylaşımının sağlanmasıdır. Bu süreçte genellikle en çok kullanılan iletişim kanalı ise online tüketici yorumlarıdır. Pazarlama literatürü içerisinde popüler olmaya başlayan online yorum kavramı tüketicilerin satın alma kararı vermeden önce başvurduğu kaynaklar olarak tanımlanmaktadır. Online tüketici yorumları, ticari temelli kurulduğu düşünülen işletmelerin kendilerine ait web sitelerinden daha güvenilir olarak nitelendirilmektedir (Özbay, 2013). Teknolojinin gelişmesi ile günümüz rekabet ortamında işletmelerin daha başarılı satış oranlarına ulaşması açısından online yorumlar oldukça büyük önem taşımaktadır.

Tüketiciler özellikle satın alma öncesinde yeterli bilgiye sahip olmadığında diğer tüketicilerin deneyimlerine daha çok önem vermektedir. İnternet yoluyla gittikçe geniş kullanıcı alanına erişilerek, ürün ya da hizmetlerle ilgili çeşitli ve fazla fikre ulaşmak mümkündür (Han,2008). Sanal ortam da bu açıdan tüketicilerin bir araya gelebileceği platformlar sunmaktadır. Forumlar, sohbet odaları, haber grupları, eposta listeleri, kişisel web siteleri, sosyal ağlar ve bloglar gibi iletişim araçlarıyla etkileşim, müşteri sadakatini geliştirmeye katkıda bulunan etkileşimli tüketici deneyimleri sağlamaktadır (De Valck vd., 2009).

Bir ürün ya da marka hakkında çevrimiçi bilgi göndermek isteyen bir grup insan tarafından başlatılan online tüketici yorumları, internet üzerinden hedeflenen kitlenin çok ötesine erişebilecek kadar etkilidir (Lee, vd. 2008). Kişisel kullanım deneyimine dayanarak kullanıcılar tarafından oluşturulan bir tür ürün bilgisi olan online tüketici yorumlarının, pazarlama alanında yeni bir hizmet alanı yaratabileceği ayrıca tüketicilerin kendine özgü kullanım koşulları açısından en üst düzeye ulaşabilecekleri ürün ya da hizmete ulaşmaları açısından maliyetsiz satış yardımcısı olarak çalışabileceği düşünülmektedir. Birçok ürün için bu pazarlama işlevinin başarılı olması, geleneksel pazarlama iletişimi açısından imkânsız veya çok maliyetlidir. Fakat online ortamda bu maliyet ortadan kalkmakta ve başarı sağlamak mümkün olmaktadır (Chen ve Xie, 2008).

Günümüzde tüketicilerin satın alma kararı vermeden önce diğer tüketicilerin deneyimlerine başvurması artık bir gereklilik olarak görülmektedir. Bu durumda online yorumların tüketicilerin deneyimlerini paylaştığı önemli bir sosyal ortam olması bu alanda yapılacak çalışmaların önemini de artırmaktadır. Bu doğrultuda bu araştırmanın amacı online tüketici yorumlarının tüketicinin satın alma davranışı üzerindeki etkisinin kullanıcının özelliklerine göre farklılaşıp farklılaşmadığını analiz etmektir. Çalışmada online tüketici yorumlarının tüketicinin satın alma kararına etkisini belirlemek adına hazırlanan araştırma modeli ve uygulanan anket çalışmasının analiz ve bulgularına yer verilmiştir. Son olarak, sonuç kısmında araştırmanın bulguları tartışılmış ve daha sonra yapılacak çalışmalara yönelik önerilerde bulunulmuştur.

\section{Kavramsal Çerçeve}

\subsection{Elektronik Ağızdan Ağıza İletişim ve Online Tüketici Yorumları}

Ağızdan ağıza iletişim ürün ya da hizmete dair ilgili kişiler arasında yüz yüze gerçekleşen, ticari amaç gütmeyen bir iletişim biçimi olarak tanımlanmaktadır (Arndt, 1967). Pazarlama açısından potansiyel müşteriler arasında gerçekleştirilen iletişim olarak tanımlanan ağızdan ağıza iletişim (Ennew, Banerjee ve Li, 2000), tüketicilerin deneyimledikleri bir ürün veya hizmetle ilgili görüşlerini ve tavsiyelerini diğer şahıslarla paylaşmalarıyla ortaya çıkmaktadır (Derbaix ve Vanhamme, 2003). İşletmeler tarafından başlatılan iletişimlere kıyasla çoğu zaman daha güvenilir olarak algılanan ağızdan ağıza iletişim (Schiffman ve Kanuk, 1995), tüketicilerin bilgi aramalarında önemli bir rol oynamaktadır. Bu iletişim tüketicilerin konuştuğu ürün ve hizmetler hakkındaki düşüncelerin değişime uğramasına veya güçlenmesine sebep olabilmektedir (Lam ve Mizerski, 2005).

Elektronik ağızdan ağıza iletişim ise, online platformlarda işletme, ürün veya hizmetle ilgili yapılan tüm olumlu veya olumsuz yorumlar ve bunlara dayalı her türlü iletişimdir. Bu iletişim tüketici ile işletme arasında veya tüketici ile diğer tüketiciler arasında olabilir (Litvin, Goldsmith ve Pan, 2008). İletişimin yüz yüze olmaması elektronik ağızdan ağıza iletişimin, geleneksel ağızdan ağıza iletişime göre en büyük avantajlarından biridir. İnternette iletişim kuranlar diğer insanlarla birebir karşılaşmak zorunda kalmadıklarından dolayı üstlerinde daha az sosyal baskı olduğundan, kendilerini ve fikirlerini daha rahat 
ifade edebilmektedir (Sun vd., 2006). Ayrıca, geleneksel ağızdan ağıza iletişimle kıyaslandığında elektronik ağızdan ağıza iletişim daha büyük hedef kitleye erişebilme imkânı sağlamaktadır. Geleneksel ağızdan ağıza iletişimde, iletişim süreci tüketicinin çevresi ile sınırlı kalırken, online yorumlarda sayısız kullanıcıya ulaşmak mümkün olmaktadır (Park vd., 2007).

Erişilebilirliği, erişimi ve şeffaflığı (Kozinets, vd., 2010) sayesinde tüketicilerin bilgi ve deneyimlerini özgürce paylaştığı bir alan olan internet (Jones vd. 2009), bilgi arama davranışı üzerinde de büyük bir etkiye sahiptir (Peterson ve Merino, 2003). Bu etki özellikle online yorumların giderek yaygınlaşmasıyla da artmaktadır. İnternette ağızdan ağıza iletişimin bir uzantısı olarak ortaya çıkan online yorum kavramını, tüketicilerin mal ve hizmetlerle ilgili yorumlarını internet aracılığıyla birbirleri ile paylaştı̆̆ her türlü iletişim biçimi olarak tanımlamak mümkündür (Yaylı ve Bayram, 2010). İlgili ürün ve hizmet hakkında bilgi ya da deneyime sahip olan tüketiciler tarafından oluşturulan online yorumlar diğer tüketiciler için tavsiye özelliği taşımaktadır (Lee vd., 2011).

$\mathrm{Bu}$ açıdan, online yorumların bilgi vermek ve tavsiye vermek gibi çift yönlü bir işlevi vardır (Park, vd. 2007). Ürün ve hizmetler hakkında bilgi aktaran etkili birer araç olan online yorumlar, tüketiciler tarafından çoğunlukla da ikna edici tavsiyeler olarak değerlendirilmektedir (Yaylı ve Bayram, 2010). Online yorumun formatı, yorum yazarının uzmanlığı, yorumun kalitesi, yorum yazarının statüsü gibi birçok faktör, tüketicileri ikna etmesi ve satın almaya yöneltmesi açısından önem arz etmektedir (Clare, 2009). Online yorumlar, online perakende siteleri, video paylaşım siteleri, kişisel bloglar ve bağımsız tüketici platformları gibi alanlar kullanılarak yapılmaktadır (Constantinides ve Holleschovsky, 2016). Bağımsız tüketici platformları arasında özellikle şikâyet sitelerinde tüketiciler diğer tüketicileri uyarmak adına ürün veya hizmetler hakkında olumsuz deneyimlerini içeren yorumları paylaşmaktadır (Han, 2008).

\subsection{Online Tüketici Yorumlarının Satın Alma Üzerindeki Etkisi}

Tüketiciler genellikle diğer tüketicilerin satın alma kararlarındaki görüşlerinden etkilenir ve bu davranışın bazı nedenleri vardır. Bunlardan biri, satın alma öncesindeki seçenekleri daraltmaktır. Tüketiciler, ilave seçenekleri elemek adına başka tüketicilerin deneyimlerinden yararlanır (Duhan vd., 1997). Diğer bir sebep ise, çok sayıda ve çeşitte bilgiye erişme isteğidir (Goldsmith ve Horowitz, 2006). Tüketiciler karar verme sürecinde zaman maliyetinden kurtulma ve fayda maksimizasyonu sağlamak için, farklı tüketicilerin deneyimlerinden ve fikirlerinden yararlanmaktadır (Hennig-Thurau ve Walsh, 2004). Bu şekilde tüketiciler ürün ve hizmet satın almadan önce kendilerini rahatlatmış olmaktadır (Pitta ve Fowler, 2005).

Khammash ve Griffiths (2011)'a göre tüketicilerin online yorumlara başvurma nedenleri arasında karar verme aşamasında karşılaşacakları riski minimuma indirmek amacıyla ürünle ilgili bilgilere ulaşmak, bilgi arama sürecini kısaltmak ve uyumsuzluğu azaltmak yer almaktadır. Fan (2011)'a göre ise tüketiciler diğergamlık, sosyal etkileşim arzusu, memnuniyet derecesi, yardım ve intikam alma teşebbüsü nedeniyle online yorum yapmaya karar vermektedir. Bu durumda tüketiciler diğer tüketicilere yardımcı olma, sosyal ortamlarda diğer tüketicilerle etkileşime geçip kendini gerçekleştirme ihtiyacını karşılama, kullandığı üründen duyduğu memnuniyeti paylaşma ya da memnuniyetsizliği sebebiyle firmadan intikam alma sebebiyle online yorumlara başvurmaktadır.

Online yorumlar üzerine daha önce yapılan araştırmalar incelendiğinde, genellikle bu yorumların tüketicilerin satın alma kararı üzerinde etkili olduğu kanısına varıldığı görülmüştür. Diğer tüketicilerin tavsiyelerini göz önüne alan tüketiciler üzerinde online yorumların etkisi yadsınamaz bir hal almaktadır. Cengiz ve Başaran (2016), online yorumlar üzerine netnografi yönteminden yararlanarak yaptıkları araştırmada, online tüketici yorumlarının tüketici araştırmacıları tarafından incelenmeye değer olduğu kanısına varmıştır. Torun (2017), satın alma karar sürecinde tüketicilerin internetten ne denli faydalandığını araştırmaya yönelik yaptığı araştırmada, araştırmaya katılan tüketicilerin ürün ile ilgili bilgilere ilk ulaştığı yerin internet kaynakları olduğu sonucuna ulaşmıştır.

Daha önce yapılan çalışmalar (Clare, 2009; Kwon vd. 2011; Özbay 2013) tüketicilerin satın alma kararı verirken hem olumlu hem de olumsuz yorumlardan etkilendiğini göstermektedir. Olumlu tüketici yorumları, kullanıcının olumlu tutuma sahip olmasını sağlayabilir ve böylelikle ürünün satışı açısından pozitif etki yaratılabilir (Clare, 2009). Kwon vd. (2011) yaptığ araştırmada olumlu yorumların otel işletmeciliği alanında satış işlemi açısından etkili olduğu sonucuna ulaşmıştır. Özbay (2013) ise, online 


\section{P. C. Akdeniz - T. Özbölük 11/4 (2019) 3104-3119}

tüketici yorumlarına yönelik yaptığı çalışmada tüketicilerin satın alma kararında olumsuz yorumların olumlu yorumlardan çok daha etkili olduğu sonucuna ulaşmıştır. Benzer şekilde Erdil (2014) çalışmasında online tüketici yorumlarının tüketicinin satın alma kararını özellikle mağaza tercihi konusunda etkilediği ve yine olumsuz yorumların olumlu yorumlardan daha etkili olduğu sonucuna ulaşmıştır.

Online tüketici yorumlarını kullanıcının özellikleri açısından analiz eden çalışmalar (Kim vd. 2011; Akdoğan ve Akyol, 2016; Gürce ve Benli, 2017) incelendiğinde ise farklı türde sonuçların elde edildiği görülmüştür. Kim vd. (2011), online tüketici yorumları üzerine yaptığı çalışmada cinsiyetin yorum okuma nedeni üzerinde farklılık yarattığı sonucuna ulaşmıştır. Araştırma sonucuna göre; kadınlar yoruma ulaşma kolaylığı, kalite ve risk azaltma sebebiyle online yorumlara başvururken, erkekler uzmanlık seviyelerine göre online yorumlara başvurmaktadır. Akdoğan ve Akyol (2016), yapmış olduğu çalışmada online tüketici yorumlarının satın alma kararını etkilediği sonucuna ulaşmıştır. Çalışmada aynı zamanda online yorum yapma, online alışveriş yapma ve cinsiyet değişkeni arasında anlamlı_farklılığa ulaşılmıştır. Gürce ve Benli (2017)'nin çalışmasında ise tüketicilerin satın alma davranışında online yorumlardan faydalanmaları durumunda cinsiyetleri açısından anlamlı bir farklılı̆ga rastlanılmamıştır. Araştırmada, tüketicilerin online yorumlardan etkilenme düzeylerinin internette geçirilen zamana göre farklılaştı̆̆ı tespit edilmiştir.

\section{YÖNTEM}

\subsection{Araştırmanın Amacı}

$\mathrm{Bu}$ araştırmanın amacı online tüketici yorumlarının tüketici satın alma kararı üzerindeki etkisinin kullanıcıların özelliklerine (cinsiyetlerine, yaşlarına, internette günlük harcadıkları zamana ve online alışveriş sıklığına) göre farklılaşıp farklılaşmadığını belirlemektir.

\subsection{Araştırmanın Modeli ve Hipotezler}

Araştırmanın modeli hazırlanırken, kullanıcının özellikleri ve online yorumun satın alma kararına etkisi göz önünde bulundurulmuştur. Bu doğrultuda, online yorumların satın alma kararına etkisinin kullanıcının yaş, cinsiyet, günlük internet kullanım süresi ve online alışveriş sıklı̆̆1 gibi özelliklerine göre farklılaşıp farklılaşmadığını gösteren bir model hazırlanmıştır. Çalışmaya ilişkin model Şekil 1.'de yer almaktadır.

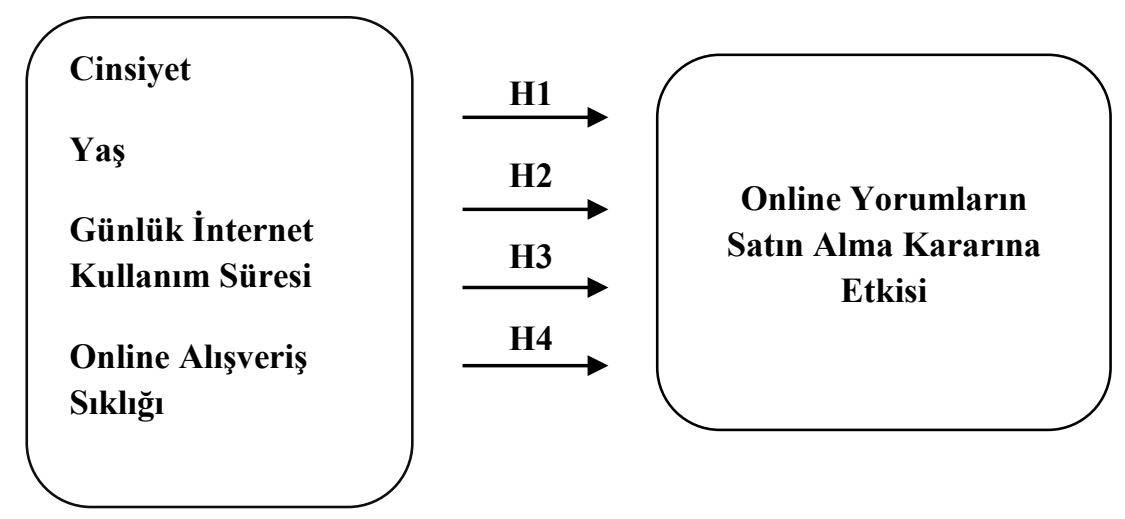

Şekil 1. Araştırmanın Modeli

Araştırmanın hipotezleri geliştirilirken, online yorumlar ve kullanıcı özellikleri arasındaki ilişkiler hakkında literatürde yer alan çalışmalar dikkate alınmıştır. Daha önceki araştırmalarda (Akdoğan ve Akyol, 2016; Yaylı ve Bayram, 2012; Stoddard vd. 2016; Gürce ve Benli, 2017) ağırlıklı olarak, cinsiyet, yaş, internet kullanım süresi ve alışveriş sıklığı değişkenlerinin incelendiği görülmüştür.

Akdoğan ve Akyol (2016) tarafından yapılan araştırmada cinsiyet ile online tüketici yorumu yazma; cinsiyet ile internetten alışveriş yapma; online tüketici yorumu yazma ve online alışveriş yapma değişkenleri açısından istatistiksel olarak anlamlı bir ilişkiye ulaşılmıştır. Bununla birlikte tüketicinin satın alma kararı vermesinde online tüketici yorumları açısından tutumun etkili olduğu tespit edilmiştir. Bu bulgular ışığında aşağıdaki H1 hipotezi geliştirilmiştir:

H1: Online yorumların satın alma kararına etkisi tüketicilerin cinsiyetlerine göre farklılık gösterir. 
Kullanıcıların yaşı ve online yorumlar arasındaki ilişkileri araştıran çalışmalar incelendiğinde ise farklı bulgulara rastlanılmaktadır. Yaylı ve Bayram kullanıcıların yaşı açısından online yorumların etkisinin farklılaşmadığını ileri sürerken, bazı araştırmalar da (Mangold ve Smith, 2011; Hall, 2018) özellikle genç kullanıcıların online yorumlardan daha fazla etkilendikleri sonucuna ulaşmıştır. Mürütsoy (2013) tarafından yapılan araştırmada da araştırma kapsamında genç olarak nitelendirilebilen yaş grubunun, orta yaş ve üstü katılımcılara oranla online alışveriş ortamını daha fazla kullandıkları sonucuna ulaşılmıştır. Bu bulgular doğrultusunda $\mathrm{H} 2$ hipotezi geliştirilmiştir:

H2: Online yorumların satın alma kararına etkisi tüketicilerin yaş aralığına göre farklılık gösterir.

Gürce ve Benli (2017) tarafından yapılan araştırmada tüketicilerin online ortamda harcanan zaman ile online tüketici yorumlarından etkilenme düzeyi arasında anlamlı farklılık tespit edilmiştir. Benzer şekilde, Yaylı ve Bayram (2012) araştırmalarında kullanıcıların sanal ortamda harcadıkları zaman ile online alışveriş sıklığı arasında, online yorumların etkisi açısından istatistiksel olarak anlamlı farklılık tespit edilmiştir. Ayrıca, Stoddard vd. (2016) tarafından gençlerin online ortamda daha fazla zaman geçirmelerinin online yorumlara duyulan güveni ve yorumların hatırlanabilirliğini artırarak daha fazla ürün satın almalarına yol açtığı bulunmuştur. Bu bulgular doğrultusunda, H3 ve H4 hipotezleri ileri sürülmüştür:

H3: Online yorumların satın alma kararına etkisi tüketicilerin günlük internet kullanım süresine göre farklılık gösterir.

H4: Online yorumların satın alma kararına etkisi tüketicilerin online alışveriş sıklığına göre farklılık gösterir.

\subsection{Veri Toplama Yöntem ve Aract}

Tanımlayıcı araştırma modeline göre hazırlanan bu araştırmada birincil verilerin toplanması amacıyla yüz yüze anket yönteminden faydalanılmıştır. Anket sorularının oluşturulmasında Yaylı ve Bayram (2012) tarafından yapılmış çalışma referans olarak alınmıştır. Anket uygulaması gerçekleştirilmeden önce, anket formunun ilk hali bir pilot teste tabi tutulmuştur. Ankette içerik açısından iyileştirme yapmak amacıyla örneklemi temsil edebilecek bir gruba pilot anket uygulaması yapılmıştır. Yapılan pilot test sonucunda ankette kullanıma uygun olmayan ifadeler saptanarak gerekli düzenlemeler yapılmış ve anket uygulamaya hazır hale getirilmiştir.

Anket formunun ilk bölümünde; kullanıcıların özelliklerini belirlemeye yönelik ifadeler yer almaktadır. Anketin ikinci bölümünde ise araştırmanın temel amacına yönelik hazırlanan 32 ifadeye yer verilmiştir. Katılımcıların kendilerine yöneltilen ifadeleri "Kesinlikle katılıyorum", "Katılıyorum", "Kararsızım", "Katılmıyorum", "Kesinlikle katılmıyorum" seçenekleri aracıllğıyla, 5’li Likert tipi ölçekle değerlendirmeleri istenmiştir.

\subsection{Araştırmanın Evren ve Örneklemi}

Araştırmanın ana kitlesini Türkiye'de online tüketici yorumlarını okuyan internet kullanıcıları oluşturmaktadır. Araştırmanın örneklemini ise evrenin büyüklüğü ve bireylere ulaşmanın zorluğu göz önünde bulundurularak kolayda örneklem yöntemine göre seçilen cevaplayıcılar oluşturmaktadır. Anket uygulaması, Eylül- Ekim 2018 tarihleri arasında, Kayseri ilinde ikamet eden ve kolayda örneklem yöntemine göre belirlenen 522 katılımcı ile yüz yüze görüşmeler aracılı̆̆ıyla gerçekleştirilmiştir. Anketlerden bir kısmının kullanılamayacak nitelikte olduğu tespit edilmiş ve 505 anket üzerinden değerlendirmeler ve analizler yapılmıştır.

\section{BULGULAR}

İlgili anket uygulamasının analizi istatistik paket programı aracılığıyla gerçekleştirilmiştir. Bu doğrultuda ankette kullanılan ifadelerin tutarlılı̆̆ının ve ölçeğin güvenilirliğinin tespiti amacıyla güvenilirlik analizi uygulanmıştır. Online yorumların satın alma kararına etkisini oluşturan boyutları belirlemek amacıyla faktör analizi ve bu boyutlar ile ilgili algılamaların kullanıcı özelliklerine göre farklılaşıp farklılaşmadığının tespiti için de Tek Yönlü Manova analizi uygulanmıştır. Güvenilirlik ve faktör analizinde değişkenler; online yorumların satın alma kararına etkisini belirlemeye yönelik ifadeler olarak belirlenirken, Tek Yönlü Manova analizinde kullanıcı özellikleri bağımsız değişken ve online yorumların satın alma kararına etkisinin boyutları da bağımlı değişken olarak belirlenmiştir. 


\subsection{Demografik Verilerin Analizi}

Cevaplayıcıların demografik bilgilerini öğrenmeye yönelik yöneltilen sorulara verilen cevapların analizine Tablo 1.'de yer verilmiştir. Bu doğrultuda anket uygulamasına katılan cevaplayıcılardan 261'inin kadın, $244^{\prime}$ ünün ise erkek olduğu görülmektedir. Bunun yanında cevaplayıcılardan 229'unun 18-29 yaş, 173'ünün 30-39 yaş, 68' inin 40-49 yaş ve 35'inin ise 50 ve üstü yaş aralığında olduğu tespit edilmiştir.

Tablo 1. Cevaplayıcıların Kişisel (Demografik) Özelliklerine İlişkin Frekans ve Yüzde Dağılımı

\begin{tabular}{|c|c|c|}
\hline & Frekans & Yüzde \\
\hline \multicolumn{3}{|c|}{ Araştırmaya Katılanların Cinsiyeti } \\
\hline Kadın & 261 & 51,7 \\
\hline Erkek & 244 & 48,3 \\
\hline Toplam & 505 & 100,0 \\
\hline \multicolumn{3}{|c|}{ Araştırmaya Katılanların Yaş Aralığı } \\
\hline $18-29$ & 229 & 45,3 \\
\hline $30-39$ & 173 & 34,3 \\
\hline $40-49$ & 68 & 13,5 \\
\hline 50 ve üstü & 35 & 6,9 \\
\hline Toplam & 505 & 100,0 \\
\hline \multicolumn{3}{|c|}{ Günlük İnternet Kullanım Süresi } \\
\hline 1 saatten az & 94 & 18,6 \\
\hline $1-5$ saat & 316 & 62,6 \\
\hline 5-10 saat & 77 & 15,2 \\
\hline 10-20 saat & 17 & 3,4 \\
\hline 20 ve üzeri saat & 1 & 0,2 \\
\hline Toplam & 505 & 100,0 \\
\hline \multicolumn{3}{|l|}{ Online Alışveriş Sıklığ1 } \\
\hline Haftada bir & 14 & 2,8 \\
\hline Haftada birkaç kez & 17 & 3,4 \\
\hline Ayda bir kez & 65 & 12,9 \\
\hline Ayda birkaç kez & 79 & 15,6 \\
\hline Diğer (ihtiyaç olduğunda) & 294 & 58,2 \\
\hline Hiç yapmadım & 36 & 7,1 \\
\hline Toplam & 505 & 100,0 \\
\hline
\end{tabular}

Katılımcllara yöneltilen günlük internet kullanım sürelerinin tespitine ilişkin sorunun analizinden hareketle çoğunlukla cevaplayıcıların günde 1-5 saat aralığında internet kullandıkları tespit edilmiştir. Online alışveriş sıklığına dair yöneltilen sorunun cevap tablosu incelendiğinde de cevaplayıcıların yüzde 58,2'sinin, kısaca büyük çoğunluğunun ihtiyaç olduğunda online alışveriş yaptıkları görülmektedir.

Demografik veri analizine ek olarak cevaplayıcıların internet aracılığılla satın aldıkları ürün türünün tespiti amacıyla yöneltilen soruya verilen cevapların analizi Tablo 2.'de yer almaktadır. Bu doğrultuda cevaplayıcıların sanal ağlar üzerinden en fazla giyim türünde alışveriş yaptıkları ve bu seçeneği sırasıyla kırtasiye, hediyelik eşya, elektronik ve küçük ev aletlerinin takip ettiği görülmektedir. 
P. C. Akdeniz - T. Özbölük 11/4 (2019) 3104-3119

Tablo 2. Cevaplayıcıların Online Ürün Alışveriş Tercih Durumu

\begin{tabular}{lcc}
\hline Ürün & Ortalama & $\begin{array}{c}\text { Standard } \\
\text { Sapma }\end{array}$ \\
\hline Giyim & 3,10 & 1,27 \\
Kirtasiye & 2,88 & 1,37 \\
Hediyelik Eşya & 2,63 & 1,31 \\
Elektronik & 2,32 & 1,21 \\
Küçük Ev Aletleri & 2,32 & 1,20 \\
Spor Malzemeleri & 2,21 & 1,26 \\
Kozmetik Ürünler & 2,20 & 1,35 \\
Mobilya & 2,14 & 1,11 \\
\hline
\end{tabular}

4.2. Faktör Analizi ve Güvenirlik Analizi

Anket uygulamasında yer alan ifadelerin tutarlılığını tespit etmek adına uygulanan güvenilirlik analizine göre Cronbach Alfa değeri 0.911 'dir (Tablo 3.). Elde edilen bu değer ise kullanılan ölçeğin güvenilirliğinin yüksek olduğunu kanıtlamaktadır.

Tablo 3. Güvenirlik Analizi

\begin{tabular}{cc}
\hline Cronbach's Alpha Değeri & İfade Sayısı \\
\hline 0,911 & 32 \\
\hline
\end{tabular}

Anket uygulamasında yer alan ifadelerin boyutlarına ulaşmak adına yapılan faktör analizi sonucunda ise KMO testi 0.904 olarak tespit edilmiştir ve Bartlett testi de anlamlı bulunmuştur (Sig.=0.000).

Tablo 4. Online Yorumların Satın Alma Kararına Etkisini Belirlemeye Yönelik Boyutların Açıkladıkları Varyans Yüzdeleri, Özdeğerleri ve İfadeleri

\begin{tabular}{|c|c|c|c|}
\hline Boyutlar & Özdeğer & Açıklanan Varyans Yüzdeleri & İfadeler \\
\hline Yorumun Etkisi & 7,445 & 33,839 & $\begin{array}{l}\text { Bilinçli Tüketici } \\
\text { Güven } \\
\text { Tercih } \\
\text { Bilgi Alma } \\
\text { Karar }\end{array}$ \\
\hline Yorumcunun Özellikleri & 3,001 & 13,643 & $\begin{array}{l}\text { İkamet Yeri } \\
\text { Cinsiyet } \\
\text { Yaş } \\
\text { Mesaj Gönderme Sıklığ }\end{array}$ \\
\hline Web Sitesinin Özellikleri & 1,529 & 6,952 & $\begin{array}{l}\text { Popülerlik } \\
\text { Uluslararası Olması } \\
\text { Güvenlik } \\
\text { Yorum Sıklığı }\end{array}$ \\
\hline $\begin{array}{l}\text { Tüketicilerin Yorum } \\
\text { Araştırma Eğilimi }\end{array}$ & 1,210 & 5,499 & $\begin{array}{l}\text { Sikâyet Siteleri } \\
\text { İnternette Araştırma } \\
\text { Tüketici Yorumlarını } \\
\text { Okuma }\end{array}$ \\
\hline Yorumun Özellikleri & 1,097 & 4,987 & $\begin{array}{l}\text { Olumlu - Olumsuz } \\
\text { Olması } \\
\text { Tutarlılık } \\
\text { Sayı } \\
\text { Puan } \\
\text { Benzerlik }\end{array}$ \\
\hline Toplam & & 64,921 & \\
\hline
\end{tabular}


P. C. Akdeniz - T. Özbölük 11/4 (2019) 3104-3119

Faktör analizi sonucunda öz değerleri 1'den büyük, 5 boyut elde edilmiştir. Bu boyutların; özdeğerleri, açıkladıkları varyans yüzdeleri ve ifadeleri Tablo 4.'te yer almaktadır. Tablodan da görüldüğü üzere boyutlar toplamda varyansın yüzde 64,921'ini açıklamaktadır.

\subsection{Tek Yönlü MANOVA Analizleri}

Online yorumların tüketici satın alma kararına etkisinin tüketicilerin özelliklerine göre farklılaşıp farklılaşmadığını tespit etmek amacıyla Tek Yönlü MANOVA analizleri yapılmıştır.

\subsubsection{Cinsiyet Değişkeni İçin MANOVA Analizi}

Online yorumların satın alma kararı üzerindeki etkisinin tüketicilerin cinsiyetlerine göre farklılık gösterip göstermediğini tespit etmek amacıyla Tek yönlü MANOVA analizi uygulanmıştır. İlgili analiz sonuçlarını gösteren tablolar aşağıda yer almaktadır.

Tablo 5. Cinsiyet Değişkeni İçin Tek Yönlü MANOVA Çok Değişkenli Test Tablosu

\begin{tabular}{|c|c|c|c|c|}
\hline \multirow[t]{3}{*}{ ETKI } & & Değer & F & Anlamlılık \\
\hline & Pillai's Trace & ,013 & $1,320^{\mathrm{b}}$ & ,254 \\
\hline & Wilks' Lambda & 987 & $1,320^{\mathrm{b}}$ & 254 \\
\hline \multirow[t]{2}{*}{ Cinsiye } & Hotelling's Trace & 013 & $1,320^{\mathrm{b}}$ & 254 \\
\hline & $\begin{array}{l}\text { Roy's Largest } \\
\text { Root }\end{array}$ & ,013 & $1,320^{\mathrm{b}}$ & ,254 \\
\hline
\end{tabular}

Tablo 5.'ten de görüldügü üzere Wilk's Lambda anlamlılık değeri 0,05'ten büyük olduğu için H1 hipotezi reddedilir. Bu durumda online yorumların satın alma kararı üzerinde etkisi tüketicilerin cinsiyetlerine göre istatistiksel olarak anlamlı bir farklılık göstermemektedir.

Tablo 6. Online Yorumların Cinsiyete Göre Satın Alma Kararına Etkisi

\begin{tabular}{llccccc}
\hline \multirow{2}{*}{ Kaynak } & \multicolumn{1}{c}{ Bağımlı Değişken } & $\begin{array}{c}\text { Kareler } \\
\text { Toplamı }\end{array}$ & $\begin{array}{c}\text { Serbestlik } \\
\text { Derecesi }\end{array}$ & $\begin{array}{c}\text { Ortalama } \\
\text { Kare }\end{array}$ & F & Anlamlılık \\
\hline \multirow{6}{*}{ Cinsiyet } & Yorumun Etkisi &, 007 & 1 &, 007 &, 012 &, 911 \\
& Yorumcunun Özellikleri & 1,010 & 1 & 1,010 & 1,031 &, 311 \\
& Web Sitesinin Özellikleri &, 021 & 1 &, 021 &, 035 &, 851 \\
& Tüketicilerin Yorum & 1,448 & 1 & 1,448 & 2,025 &, 155 \\
& Araştırma Eğilimi &, 451 & 1 &, 451 & 1,007 &, 316 \\
& Yorumun Özellikleri & & & & & \\
\end{tabular}

Anlamlılık seviyesi her boyut için de 0,05'ten büyük olduğu için (Tablo 6.) online tüketici yorumlarına ilişkin boyutların hiçbirinin katılımcıların cinsiyetleri açısından anlamlı bir farklılık göstermediği görülmektedir.

\subsubsection{Yaş Değişkeni İ̧̧in MANOVA Analizi}

Online yorumların satın alma kararı üzerindeki etkisinin tüketicilerin yaş aralığına göre farklılık gösterip göstermediğini tespit etmek amacıyla yapılan Tek Yönlü MANOVA analizi sonuçlarına aşağıdaki tablolarda yer verilmiştir. 
Tablo 7. Yaş Değişkeni İçin Tek Yönlü MANOVA Çok Değişkenli Test Tablosu

\begin{tabular}{llccc}
\hline Etki & & Değer & F & Anlamlılık \\
\hline \multirow{2}{*}{ Yaş } & Pillai's Trace &, 044 & 1,486 &, 102 \\
& Wilks' Lambda &, 956 & 1,490 &, 101 \\
& Hotelling's Trace &, 045 & 1,493 &, 005 \\
& Roy's Largest Root &, 034 & $3,379 c$ &, \\
\hline
\end{tabular}

Tablo 7. incelendiğinde, Wilks' Lambda anlamlılık değerinin $(0,101) 0,05^{\prime}$ ten büyük olduğu görülmektedir. $\mathrm{Bu}$ durumda $\mathrm{H} 2$ hipotezi reddedilir ve ürüne yönelik online tüketici yorumlarının satın almaya etkisinin cevaplayıcıların yaş aralıklarına göre anlamlı farklılık göstermediği tespit edilmiştir.

Tablo 8. Online Yorumların Yaşa Göre Satın Alma Kararına Etkisi

\begin{tabular}{lcccccc}
\hline Kaynak & \multicolumn{1}{c}{ Bağımlı Değişken } & $\begin{array}{c}\text { Kareler } \\
\text { Toplamı }\end{array}$ & $\begin{array}{c}\text { Serbestlik } \\
\text { Derecesi }\end{array}$ & $\begin{array}{c}\text { Ortalama } \\
\text { Kare }\end{array}$ & F & Anlamlılık \\
\hline Yorumun Etkisi & 5,257 & 3 & 1,752 & 3,056 &, 028 \\
$\quad$ Yorumcunun Özellikleri & 3,825 & 3 & 1,275 & 1,303 &, 273 \\
$\quad \begin{array}{l}\text { Web Sitesinin } \\
\text { Yaş }\end{array}$ & 3,706 & 3 & 1,235 & 2,096 &, 100 \\
$\begin{array}{l}\text { Özellikleri } \\
\text { Tüketicilerin Yorum }\end{array}$ &, 201 & 3 &, 067 &, 093 &, 964 \\
$\quad \begin{array}{l}\text { Araştırma Eğilimi } \\
\text { Yorumun Özellikleri }\end{array}$ & 1,032 & 3 &, 344 &, 767 &, 513 \\
\hline
\end{tabular}

Online tüketici yorumlarının boyutları açısından değerlendirildiğinde ise, yalnızca birinci değişken (yorumun etkisi) itibariyle tüketicilerin yaş grupları arasında anlamlı bir farklılığa rastlanmıştır. Bu durumda yaş gruplarına ilişkin farklılık sadece "yorumların etkisi" için anlamlı çıkmıştır. Ancak çok değişkenli test tablosunda Wilks' Lambda anlamlılık değeri 0,05'ten büyük olduğu için, analiz açısından bu farklılık bir anlam ifade etmemektedir.

\subsubsection{Günlük İnternet Kullanım Süresi Değişkeni İçin MANOVA Analizi}

Online tüketici yorumlarının satın alma kararı üzerindeki etkisinin tüketicilerin günlük internet kullanım süresine göre farklılık gösterip göstermediğini anlayabilmek amacıyla yapılan tek yönlü MANOVA analizinin sonuçları aşağıdaki tablolarda yer almaktadır.

Tablo 9. Günlük İnternet Kullanım Süresine Yönelik Tek Yönlü MANOVA Çok Değişkenli Test Tablosu

\begin{tabular}{llccc}
\hline Etki & & Değer & F & Anlamlılık \\
\hline Günlük & Pillai's Trace &, 046 & 1,153 &, 287 \\
İnternet & Wilks' Lambda &, 955 & 1,154 &, 286 \\
Kullanım & Hotelling's Trace &, 047 & 1,154 &, 286 \\
Süresi & Roy's Largest Root &, 026 & $2,638^{c}$ &, 023 \\
\hline
\end{tabular}

Tablo 9. incelendiğinde Wilks' Lambda anlamlılık değerinin 0,286 olduğu görülmektedir. Bu durumda günlük internet kullanım süresi bağımsız değişkeni için kurulan hipotez reddedilir. Ürüne yönelik online 
P. C. Akdeniz - T. Özbölük 11/4 (2019) 3104-3119

tüketici yorumlarının satın almaya etkisi, tüketicilerin günlük internet kullanım süresi açısından istatistiksel olarak anlamlı bir farklılık göstermemektedir.

Tablo 10. Online Yorumların Günlük İnternet Kullanım Süresine Göre Satın Alma Kararına Etkisi

\begin{tabular}{|c|c|c|c|c|c|c|}
\hline Kaynak & Bağımlı Değişken & $\begin{array}{c}\text { Kareler } \\
\text { Toplamı } \\
\end{array}$ & $\begin{array}{c}\text { Serbestlik } \\
\text { Derecesi } \\
\end{array}$ & $\begin{array}{c}\text { Ortalama } \\
\text { Kare }\end{array}$ & $\mathbf{F}$ & Anlamlılık \\
\hline \multirow{5}{*}{$\begin{array}{c}\text { Günlük } \\
\text { İnternet } \\
\text { Kullanım } \\
\text { Süresi }\end{array}$} & Yorumun Etkisi & ,866 & 4 & ,217 & 371 & 829 \\
\hline & Yorumcunun Özellikleri & 5,334 & 4 & 1,333 & 1,364 & ,245 \\
\hline & Web Sitesinin Özellikleri & 3,707 & 4 & ,927 & 1,569 & 181 \\
\hline & $\begin{array}{l}\text { Tüketicilerin Yorum } \\
\text { Araştırma Eğilimi }\end{array}$ & 4,950 & 4 & 1,237 & 1,737 & ,140 \\
\hline & Yorumun Özellikleri & 906 & 4 & ,227 &, 504 & 733, \\
\hline
\end{tabular}

Varyans analizi tablosuna baktığımızda sonuç faktörler açısından da görülmektedir. Tablo 10'a ait değerler incelendiğinde hiçbir faktör için ürüne yönelik online tüketici yorumlarının satın almaya etkisinin günlük internet kullanım süresine göre istatistiksel olarak anlamlı bir farklılık göstermediği görülmektedir.

\subsubsection{Online Alışveriş Sıklı̆̆ı Değiş̧keni İçin MANOVA Analizi}

Online tüketici yorumlarının satın alma kararı üzerindeki etkisinin tüketicilerin online alışveriş sıklığı açısından farklılaşıp farklılaşmadığına ilişkin tek yönlü MANOVA analizi sonuçları aşağıdaki tablolarda yer almaktadir:

Tablo 11. Online Alışveriş Sıklığına Yönelik Tek Yönlü MANOVA Çok Değişkenli Test Tablosu

\begin{tabular}{llccc}
\hline Etki & & Değer & F & Anlamlılık \\
\hline Online & Pillai's Trace &, 104 & 2,110 &, 001 \\
Alışveriş & Wilks' Lambda &, 899 & 2,134 &, 001 \\
Sıklığı & Hotelling's Trace &, 109 & 2,150 &, 001 \\
& Roy's Largest Root &, 070 & $6,996^{c}$ &, 000 \\
\hline
\end{tabular}

Tablo 11. incelendiğinde Wilks' Lambda değerinin 0,05 'ten küçük olduğu görülmektedir. Bu durumda online alışveriş sıklığı bağımsız değişkeni için kurulan hipotez kabul edilir. Ürüne yönelik online tüketici yorumlarının satın almaya etkisi cevaplayıcıların online alışveriş sıklığına göre istatistiksel olarak anlamlı bir farklılık göstermektedir.

Tablo 12. Online Yorumların Online Alışveriş Sıklığına Göre Satın Alma Kararına Etkisi

\begin{tabular}{clccccc}
\hline \multirow{2}{*}{ Kaynak } & \multicolumn{1}{c}{ Bağımlı Değişken } & $\begin{array}{c}\text { Kareler } \\
\text { Toplamı }\end{array}$ & $\begin{array}{c}\text { Serbestlik } \\
\text { Derecesi }\end{array}$ & $\begin{array}{c}\text { Ortalama } \\
\text { Kare }\end{array}$ & F & Anlamlılık \\
\hline & Yorumun Etkisi & 2,576 & 5 &, 515 &, 887 &, 490 \\
& Yorumcunun Özellikleri & 6,099 & 5 & 1,220 & 1,248 &, 286 \\
$\begin{array}{c}\text { Online } \\
\text { Alışveriş SıklığıTüketicilerin Yorum }\end{array}$ & Web Sitesinin Özellikleri & 13,646 & 5 & 2,729 & 4,773 &, 000 \\
& Araştırma Eğilimi & 6,406 & 5 & 1,281 & 1,802 &, 111 \\
& Yorumun Özellikleri & 7,774 & 5 & 1,555 & 3,560 &, 004 \\
\hline
\end{tabular}

Tablo 12. incelendiğinde online tüketici yorumlarının satın almaya etkisinin iki boyut açısından farklılaştığı görülmektedir. Yorumun özellikleri faktörü ve web sitesinin özellikleri faktörünün satın almaya etkisi tüketicilerin online alışveriş sıklığına göre anlamlı bir farklılık göstermektedir. Bu farklılıkların nereden kaynaklandığını anlayabilmek amacıyla Tukey testlerine bakılmıştır.

Web sitesinin özellikleri boyutunda oluşan anlamlı farklılığın nereden kaynaklandığını gösteren Tukey testinin sonuçları Tablo 13.'te yer almaktadır. Tukey testi sonucuna göre, web sitesinin özellikleri açısından online alışveriş sıklığı değişkeninden kaynaklanan farklılık, haftada bir kez diye cevaplayanlar hariç diğer 
P. C. Akdeniz - T. Özbölük 11/4 (2019) 3104-3119

tüm cevaplar ve hiç yapmadım cevabı verenler arasında ortaya çıkmaktadır. Bu durumda, online tüketici yorumlarının satın almaya etkisi boyutlarından olan web sitesinin özelliklerinin değerlendirilmesinin, tüketicilerin online alışveriş sıklığına göre farklılaştığı söylenebilir.

Tablo 13. Web Sitesinin Özelliklerine Göre Tukey Testi Sonuçları

\begin{tabular}{|c|c|c|c|c|c|c|}
\hline Bağımlı D & eğişken & $\begin{array}{c}\text { (I) Online } \\
\text { Alışveriş Sıklığı }\end{array}$ & $\begin{array}{c}\text { (J) Online Alışveriş } \\
\text { Sıklığı }\end{array}$ & $\begin{array}{c}\text { Ortalama } \\
\text { Fark1 } \\
\text { (I-J) }\end{array}$ & $\begin{array}{c}\text { Standard } \\
\text { Sapma }\end{array}$ & Anlamlılık \\
\hline & & & Haftada Birkaç Kez &,- 6870 & 27292 & ,121 \\
\hline & & & Ayda Bir Kez &,- 3852 & ,22281 &, 513 \\
\hline & & Haftada Bir & Ayda Bir Kaç Kez &,- 2821 & 21928 & 792 \\
\hline & & & Diğer &,- 2976 & ,20686 & 703 \\
\hline & & & Hiç Yapmadım & 2183 & 23818 & ,942 \\
\hline & & & Haftada Bir & 6870 & ,27292 & 121 \\
\hline & & & Ayda Bir Kez & ,3018 & 20600 & 687 \\
\hline & & Koa & Ayda Bir Kaç Kez & 4049 & 20218 & ,342 \\
\hline & & & Diğer & 3894 & 18863 & 308 \\
\hline & & & Hiç Yapmadım & ,9052* & ,22254 & ,001 \\
\hline & & & Haftada Bir & ,3852 & ,22281 & ,513 \\
\hline & & & Haftada Birkaç Kez &,- 3018 & 20600 & 687 \\
\hline & & Ayda Bir Kez & Ayda Bir Kaç Kez & 1031 & , 12663 & ,965 \\
\hline & & & Diğer & ,0875 & 10365 & ,959 \\
\hline Web Sitesinin & (1) & & Hiç Yapmadım & $6034^{*}$ & 15710 & ,002 \\
\hline Özellikleri & & & Haftada Bir & 2821 & 21928 & ,792 \\
\hline & & & Haftada Birkaç Kez &,- 4049 & 20218 & 342 \\
\hline & & Ayda Bir Kaç Kez & Ayda Bir Kez &,- 1031 & 12663 & ,965 \\
\hline & & & Diğer &,- 0155 & ,09583 & 1,000 \\
\hline & & & Hiç Yapmadım &, $5004^{*}$ & 15206 & ,014 \\
\hline & & & Haftada Bir & 2976 & 20686 & 703 \\
\hline & & & Haftada Birkaç Kez &,- 3894 & 18863 & ,308 \\
\hline & & Diğer & Ayda Bir Kez &,- 0875 & 10365 & ,959 \\
\hline & & & Ayda Bir Kaç Kez & ,0155 & ,09583 & 1,000 \\
\hline & & & Hiç Yapmadım &, $5159^{*}$ & 13353 & ,002 \\
\hline & & & Haftada Bir &,- 2183 & 23818 & ,942 \\
\hline & & & Haftada Birkaç Kez &,$- 9052^{*}$ & ,22254 & ,001 \\
\hline & & Hiç Yapmadım & Ayda Bir Kez &,$- 6034^{*}$ & 15710 & ,002 \\
\hline & & & Ayda Bir Kaç Kez &,$- 5004^{*}$ & 15206 & ,014 \\
\hline & & & Diğer &,$- 5159^{*}$ & 13353 & ,002 \\
\hline
\end{tabular}

Tablo 14.'te yorumun özellikleri açısından ele alınan Tukey Testi sonuçlarına göre de haftada birkaç kez cevabını veren katılımcılar ile hiç yapmadım cevabını veren katılımcılar; ayda bir kez ile hiç yapmadım 
P. C. Akdeniz - T. Özbölük 11/4 (2019) 3104-3119

cevabını veren katılımcılar; ayda birkaç kez cevabını veren katılımcılar ile hiç yapmadım cevabını veren katılımcılar; diğer cevabını veren katılımcılar ile hiç yapmadım cevabını veren katılımcılar arasında anlamlı bir farklılık olduğu görülmektedir.

Tablo 14. Yorumun Özelliklerine Göre Tukey Testi Sonuçları

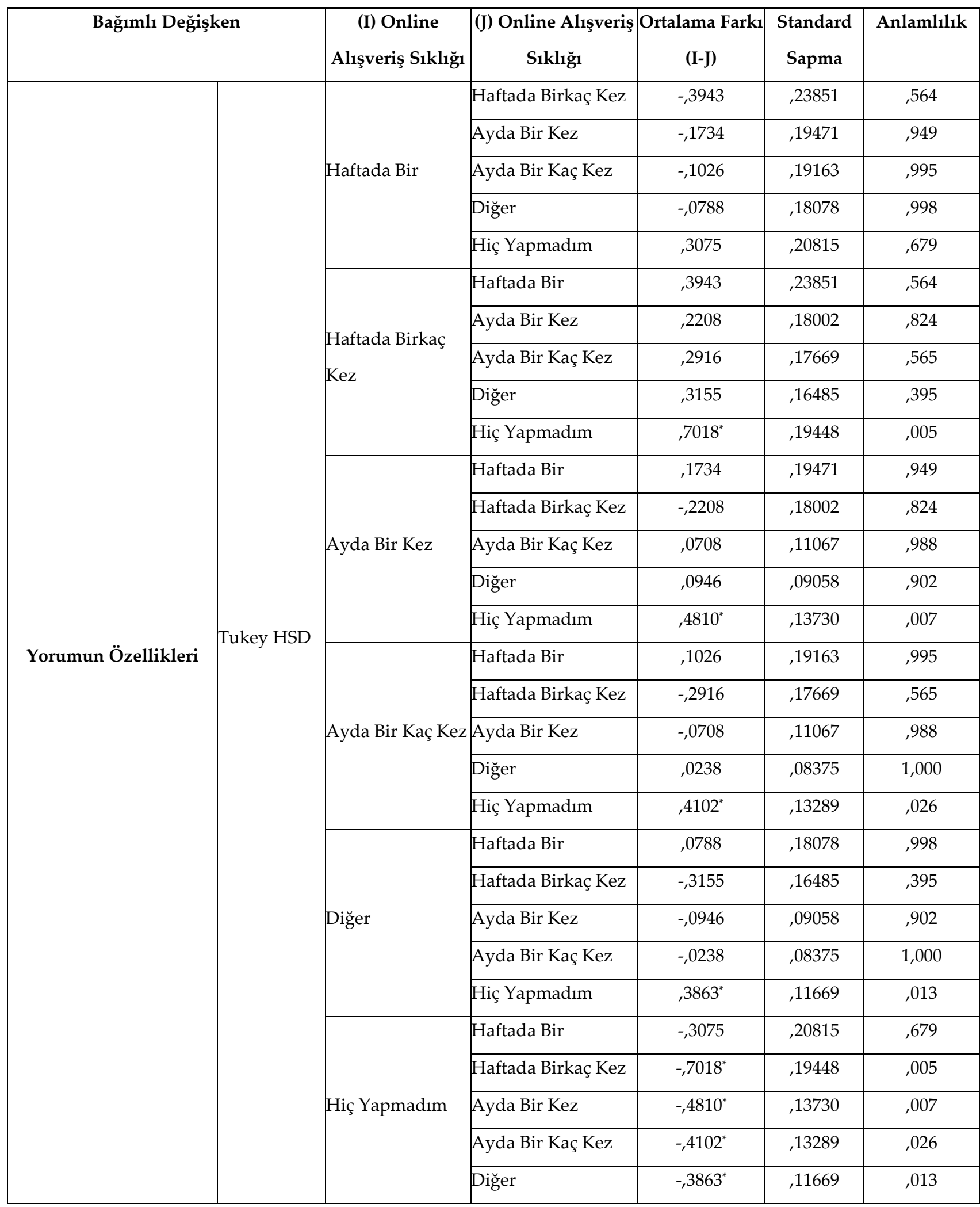

Tek yönlü MANOVA analizleri sonucunda web sitesinin özellikleri ve yorumun özelliklerinin, satın almaya etkisinin tüketicilerin online alışveriş sıklığına göre anlamlı bir farklılık gösterdiği sonucuna ulaşılmıştır. Bu doğrultuda ele alınan Tukey Testi sonuçlarından da yola çıkılarak tüketicilerin online alışveriş sıklıkları 
arttıkça satın alma kararları üzerinde web sitesinin özellikleri ve yorumun özelliklerinin daha etkili olduğu ortaya çıkmıştır.

\section{SONUÇ VE ÖNERILLER}

Son yıllarda, tüketicilerin birbirleriyle iletişim kurmak ve bilgi almak için interneti daha fazla kullanmaları online yorumların önemini de giderek artırmıştır. İnternetin bir iletişim kanalı haline gelmesi, coğrafi olarak dağınık olan bireylerin bir araya gelmesini sağlamış, böylece sanal dünya yalnızca işletmeleri değil, tüketicileri de birbirine bağlayarak çevrimiçi içerik ve iletişimi artırmıştır. Tüketicilerin bir ürün satın almadan önce diğer tüketicilerin deneyimlerini öğrenme ihtiyacı duyması ve bu verilere en fazla ve çeşitli ulaşım yolunun internetten geçmesi, online yorumların tüketiciye sınırsız bilgi imkânı ile yol gösterme deneyimi sunmasını sağlamaktadır. Tüketicilerin günümüzde son derece önem verdiği online yorumlar işletmeleri olumlu ya da olumsuz yönde etkileme yetisine sahiptir ve artık işletmeler için önemli hale gelen online itibarlarını da doğrudan etkilemektedir. Online tüketici yorumları bu anlamda hem işletmelerin hem de tüketicilerin satın alma sürecinde önemli bir yardımcısıdır.

$\mathrm{Bu}$ araştırmanın amacı, ürüne yönelik online yorumların tüketici satın alma kararı üzerindeki etkisini kullanıcının özellikleri açısından değerlendirmektir. Araştırma sonucunda, tüketicilerin satın alma kararı üzerinde ürüne yönelik online yorumların etkisinin cevaplayıcıların cinsiyet, yaş grupları ve günlük internet kullanım süresi değişkenlerine göre anlamlı bir farklılık göstermediği sonucuna ulaşılmıştır. Bu sonuç Gürce ve Benli tarafından 2017 yılında yapılan çalışmayla karşılaştırıldığında, araştırmaya katılan cevaplayıcıların satın alma kararında online tüketici yorumlarından etkilenme durumunda benzer şekilde cinsiyet değişkeni açısından anlamlı bir farklılığın bulunamadığı görülmüştür. Yaylı ve Bayram (2012) tarafından yapılan araştırmada da MANOVA analizi sonucunda cinsiyet ve yaş değişkeni için anlamlı bir farklılık bulunamamış, yalnızca internet kullanım süresi ve online alışveriş sıklığına göre anlamlı bir farklılık tespit edilmiştir.

Öte yandan bu araştırmada online alışveriş sıklığı değişkeni açısından anlamlı bir farklılığa rastlanmıştır. Anlamlı farklılık gösteren faktörlerin incelenmesi adına yapılan tek yönlü MANOVA analizine göre; yorumun özellikleri ve web sitesinin özellikleri faktörlerinin satın almaya etkisinin tüketicilerin online alışveriş sıklığına göre anlamlı bir farklılık gösterdiği anlaşılmaktadır. Bu durumda tüketicilerin online alışveriş sıklıkları arttıkça satın alma kararları üzerinde web sitesinin özellikleri ve yorumun özelliklerinin daha etkili olduğu söylenebilir. Başka bir deyişle, online alışveriş sıklı̆̆ daha fazla olan tüketicilerin satın alma kararı vermek için online yorumları incelerken web sitesinin popüler, tanıdık ve güvenilir olmasından daha fazla etkilendikleri; bu tüketiciler için online yorumların olumlu ya da olumsuz olmasının, tutarlılığının, sayısının, aldığı puanın vb. özelliklerinin daha fazla önem arz ettiği anlaşılmaktadır.

Bu bulguların işletmeler açısından da yol gösterici olacağı düşünülmektedir. Online yorumların giderek yaygınlaşması neticesinde, işletmeler hem olumlu hem de olumsuz yorumların ürünleri üzerindeki etkisinin farkında olmalıdır. Bugün bir ürün için listelenen yorum sayısı ne kadar fazlaysa tüketicilerin satın alma kararında bu yorumlardan etkilenme düzeyi de o kadar artmaktadır. Bu nedenle işletmelerin online satış için özellikle yorum sıklı̆ğın daha fazla olduğu güvenilir ve popüler platformları tercih etmeleri önerilmektedir. Ayrıca, işletmelerin kendi web sitelerinde de kullanıcı yorumlarına yer vermeleri, ancak bunu yaparken web sitesinin daha güvenilir olarak algılanmasını sağlayacak özelliklere ağırlık verilmesi, güvenlik, yorum sıklığı gibi web sitesi özelliklerini de artırmaları gerekmektedir.

Online ortamda içerik üreticisinin işletmelerden çok tüketicilerin olması, dolayısıyla da kontrolün giderek üreticiden tüketiciye geçmesi, geleneksel pazarlama yöntemlerinin de sorgulanmasını gerektirmektedir. Bilginin şeffaflığı neticesinde ürün ve markalara yönelik eleştirilerin çok daha ağırlaştığı bir ortamda ürün ve marka yöneticileri de sadece gözlem yapmakla kalmayıp, online ortamdaki tartışmalara aktif olarak katılarak ürün ya da marka hakkında bilgi sağlayabilirler. Özellikle olumsuz yorumların işletmeler tarafından ciddiye alınması ve tüketicilerle iletişimsizliğin olumsuz bilginin yayılmasını artıracağı unutulmamalıdır. Bu açıdan marka yöneticilerinin markayla ilgili her şeyi kontrol etmeye çalışan geleneksel marka yöneticisi rolünden çıkıp, iletişimde daha katılımcı bir rol benimsemeleri gerekmektedir.

$\mathrm{Bu}$ araştırma kapsamında ürüne yönelik online yorumların satın alma kararı üzerindeki etkisinin kullanıcının özelliklerine göre farklılaşıp farklılaşmadığı analiz edilmiştir. Online tüketici yorumlarıyla ilgili 


\section{P. C. Akdeniz - T. Özbölük 11/4 (2019) 3104-3119}

literatüre katkı sağlayacak bu araştırmada yalnızca ürüne ilişkin yorumların satın alma üzerindeki etkisi araştııılmıştır. Daha sonraki araştırmalarda, online mağaza yorumları ya da mağazaların yer aldığı online platformlara ilişkin yorumların tüketici satın alma kararında ne kadar etkili olduğu araştırılabilir. Ayrıca, araştırma sadece Kayseri il merkezinde yaşayan tüketiciler üzerinde gerçekleştirilmiştir. Bu anlamda araştırma sonuçlarının tüm ülkeye genellenebilmesi de mümkün değildir. Kolayda örneklem yöntemine göre belirlenen bu araştırmanın hedef kitlesi diğer araştırmaların farklı örneklem gruplarıyla yapılmasına öneri olarak sunulabilir. Örneklemde geniş bir çeşitliliğin sağlanması açısından, Instagram, Facebook vb. sosyal medya kullanıcıları ya da ürün ve markalarla ilgili şikâyet sitelerinin kullanıcıları gibi farklı gruplar üzerinde yapılacak araştırmalar elde edilen sonuçların geliştirilmesine katkı sağlayabilir.

\section{Kaynakça}

Akdoğan, Ç. \& Akyol, A. (2016). Online Tüketici Yorumlarına Ait Genel Tutum İle Ağızdan Ağıza Pazarlama Arasındaki İlişki, Trakya Üniversitesi Sosyal Bilimler Dergisi, 18 (1), 117-134.

Arndt, J. (1967). Role of Product-Related Conversations in the Diffusion of a New Product. Journal of Marketing Research, 52 (6), 291-295.

Cengiz, H. \& Başaran S. (2016). Cep Telefonu Kullanıcılarının Tüketici Tecrübelerinin Değerlendirilmesi: Online Tüketici Yorumları Üzerine Netnografik Bir İnceleme, Tüketici ve Tüketim Araştırmaları Dergisi, 8(1), 73-92.

Chen, Y. \& Xie, J. (2008). Online Consumer Review: Word-of-Mouth as a New Element of Marketing Communication Mix, Management Science, 54(3):477-491.

Clare, C. (2009). Mres Extended Abstract: Factors of Online Reviews that Influence Consumer-Buying Decisions in B2C e-Commerce. Doctoral Symposium, 1-8.

Constantinides, E., \& Holleschovsky, N. I. (2016). Impact of Online Product Reviews on Purchasing Decisions, Proceedings of The 12th International Conference on Web Information Systems and Technologies, 271-278.

De Valck, K., Van Bruggen, G. \& Wierenga, B. (2009). Virtual Communities: A Marketing Perspective. Decision Support Systems, Vol. 47,185-203.

Derbaix, C. \& Vanhamme, J. (2003). Inducing Word-of-Mouth by Eliciting Surprise - A Pilot Investigation. Journal of Economic Psychology, 24(1), 99-116.

Duhan, D. F., Johnson S. D., Wilcox, J.B., \& Harrell, G.D. (1997). Influences on Consumer Use of Word-ofMouth Recommendation Sources. Academy of Marketing Science Journal, 25(4), 283-295.

Ennew, C. T., Banerjee, A.K. \& Li. D. (2000). Managing Word of Mouth Communication: Empirical Evidence from India. International Journal of Bank Marketing, 18(2), 75-83.

Erdil, M. (2014). Online Tüketici Yorumlarının Tüketici Satın Alma Davranışı Üzerine Etkileri, İstanbul Üniversitesi Sosyal Bilimler Enstitüsü İşletme Ana Bilim Dalı Doktora Tezi, İstanbul.

Fan, J. (2011). Research on the External Factors of Consumer Releasing Online Comments. International Conference on Electronic \& Mechanical Engineering and Information Technology, 3819-3823.

Goldsmith, R. E., \& Horowitz, D. (2006). Measuring Motivations for Online Opinion Seeking. Journal of Interactive Advertising, 6(2), 1-16.

Gürce, M. \& Benli M. (2017). The Effects of Online Consumer Reviews On Purchase Intention: A Study For Young Consumers, Journal of Current Researches On Business and Economics,7(1), 2547-9628.

Hall, A. (2018). Most millenials only purchase items with online reviews, study finds. Independent, https://www.independent.co.uk/news/business/millennial-online-review-products-research-internettrusted-recommendations-a8245781.html

Han, S. M. (2008). Motivatıons For Providing And Seeking Ewom: A Cross Cultural Comparison Of U.S. And Korean College Students, Michigan State University 
P. C. Akdeniz - T. Özbölük 11/4 (2019) 3104-3119

Hennig-Thurau, T., Gwinner, K.P., Walsh, G. \& Gremler, D.D. (2004). Electronic Word-of-mouth via Consumer Opinion Platforms: What Motivates Consumers to Articulate Themselves on the Internet. Journal of Interactive Marketing ,18(1), 38-52

Jones, S.A., Aiken, K. D. \& Boush, D.M. (2009). Integrating Experience, Advertising, and Electronic Word of Mouth. Journal of Internet Commerce, Vol. 8, 246-267.

Khammash M. \& Griffiths, G.H. (2011). Arrivederci CIAO.Com, Buongiorno Bing.Com-Electronic word-ofmouth (eWOM), antecedences and consequences, International Journal of Information Management, 31 (1), 82-87.

Kım, E.E.K, A.S. Mattila \& S. Baloglu (2011), Effects of Gender and Expertise on Consumers' Motivation to Read Online Hotel Reviews, Cornell Hospitality Quarterly, 1-8.

Kozinets, R. V., De Valck, K., Wojnicki, A.C. \& Wilner, J.S. (2010) Networked Narratives: Understanding Word-of- Mouth Marketing in Online Communities, Journal of Marketing, 74 (2), pp. 71-89.

Kwon, J. M., Bae J.I. \& Phelan, K. (2011). Online Consumer Herding Behaviors in The Hotel Industry, Texas Tech University https://scholarworks.umass.edu/cgi/viewcontent.cgi?article=1052\&context=gradconf hospitality

Lam, D. \& Mizerski, D. (2005). The Effects of Locus of Control on Word-Of-Mouth Communication. Journal of Marketing Communications, 11(3), 215-228.

Lee, J., Do- Hyung P. \& Han, I. (2008). The Effect of Negative Online Consumer Reviews On Product Attitude: An Information Processing Review, Electronic Commerce Research and Applications, 7 (3), 341352.

Lee, J., Do- Hyung P. \& Han, I. (2011). The Different Effects of Online Consumer Reviews on Consumers' Purchase Intentions Depending on Trust in Online Shopping Malls: An Advertising Perspective", Internet Research, 21 (2), 187-206.

Litvin, S. W., Goldsmith, R. E. \& Pan, B. (2008). Electronic Word-Of-Mouth in Hospitality and Tourism Management. Tourism Management, 29(3), 458-468.

Mangold, W. G. \& Smith, K. T. (2011). Selling to Millennials with Online Reviews. Business Horizons, 55 (2), 141-153.

Mürütsoy M. (2013). İnternet Tüketicisinin Satın Alma Davranışlarının İncelenmesi Üzerine Bir Araştırma, Niğde Üniversitesi Sosyal Bilimler Enstitüsü İşletme Anabilim Dalı Üretim Yönetimi ve Pazarlama Bilim Dalı, Yüksek Lisans Tezi, Niğde.

Özbay, G. (2013). Sanal Ortamda Paylaşılan Tüketici Yorumlarının Algılanması ve Satın Almada Bilgi Kullanımına Etkisi - Otel İşletmelerinde Bir İnceleme, Sakarya Üniversitesi Sosyal Bilimler Enstitüsü, Doktora Tezi, Sakarya.

Park, D. H., Lee, J. \& Han, I. (2007). The Effect Of On-Line Consumer Reviews On Consumer Purchasing Intention: The Moderating Role Of Involvement. International Journal Of Electronic Commerce, 11 (4), $125-148$.

Park, D.H. \& Kim, S. (2008). The effects of Consumer Knowledge on Message Processing of Electronic WordOf-Mouth via Online Consumer Reviews. Electronic Commerce Research and Applications, 7, 399-410.

Peterson, R. A. \& Merino M. C., (2003). Consumer Information Search and the Internet. Psychology and Marketing, 20 (2), 99-121.

Pitta, D. A. \& Fowler, D. (2005). Online consumer communities and their value to new product developers. Journal of Product and Brand Management, 14 (5), 283-291.

Schiffman, L. G., \& Kanuk, L. L. (1995). Consumer Behavior. (9th Ed). Upper Saddle River, NJ: Prentice Hall 
P. C. Akdeniz - T. Özbölük 11/4 (2019) 3104-3119

Stoddard, J. E., Dotson, M. \& Das, N. (2016). Using Focus Groups and Correspondence Analysis to Explore the Relationship Between Millenials' Online Behavior and Their Opinions of Online Reviews. Atlantic Marketing Journal, 5(2), 55-68.

Sun, T., Youn, S., Wu, G., \& Kuntaraporn, M. (2006). Online word-of-mouth (or mouse): An exploration of its antecedents and consequences. Journal of Computer-Mediated Communication, 11(4), 1104-1127.

Torun, E. (2017). Tüketici Satın Alma Davranışları Üzerinde İnternet ve Sosyal Medyanın Yeri ve Önemi. Elektronik Sosyal Bilimler Dergisi, 16 (62), 955-970.

Yaylı, A. \& Bayram, M. (2010). E-Tüketici Yorumları: Antalya Restoranları Üzerine Bir Değerlendirme. 4. Ulusal Gastronomi Sempozyumu \& Sanatsal Etkinlikler, 1-6.

Yayll, A. \& Bayram, M. (2012). eWOM: The Effects Of Online Consumer Reviews On Purchasing Decision of Electronic Goods. Proceedings of the International Marketing Trends Conference. 